\title{
Ethics and law for medical students: the core curriculum
}

\author{
Tony Hope University of Oxford, Oxford
}

Teachers of ethics in UK medical schools have agreed a core curriculum for ethics and law, which is published in this issue of the journal. ${ }^{1}$ When I told a senior professor of medicine in my own clinical school of this consensus statement he gave a look of surprise and then shuddered. I interpret his look as astonishment that a group of medical ethicists can agree about anything. The shudder, I think, was at the thought of a uniform syllabus: will the autonomy of individual teachers, and of medical schools, be restricted, with a corresponding loss of creative innovation?

Over the last two decades, a few people, in various UK medical schools, have struggled to introduce a serious course in ethics and law. Their efforts found some support from a few doctors, but met with a great deal of resistance. There are three principal reasons typically given for resisting change: the innovation is trivial, redundant, or impossible to achieve. Some said that ethical problems in medicine seldom arise, and when they do it is obvious what should be done (trivial). Some said that ethics was being taught, not as a formal course but on ward rounds in the context of discussing individual patients (redundant). Some said that there are no right or wrong answers with regard to ethical issues, and, therefore, ethics is about attitudes and moral character and not amenable to teaching (impossible). Institutions also create their own versions of catch-22 when resisting change. The version which I confronted was this: you can't teach ethics until you have shown that your programme is effective; you can't show that the programme is effective until you have taught ethics. With all these barriers, developments have been slow and haphazard and have depended on the hard work of a few individuals.

\section{Tomorrow's doctors}

In 1993 the General Medical Council (GMC), which registers UK doctors, published a seminal document: Tomorrow's Doctors. ${ }^{2}$ This document tackles the question of what the aims and content of the medical course should be. One central issue, which concerned the GMC, was the overloading of the factual content of the curriculum, which derived from a time when postgraduate education and specialisation were the exception rather than the rule. The solution to this problem was to distinguish a core curriculum from special study modules. The core is that part that all students must learn. The special study modules are for more depth - students have to pick a number of such modules but none is compulsory. There was a second issue concerning the GMC: several topics, which in its view should be part of the core curriculum, were not being given much attention in most medical schools. Amongst these were ethics and law.

The identification, by the GMC, of ethics and law as part of the core curriculum will be of critical importance in the teaching of these subjects in UK medical schools. Of equal importance, however, is the fact that the GMC is also visiting each medical school on a regular basis (every couple of years or so) in order to find out how its recommendations are being implemented. During these visits, the GMC meets with medical students in private so as to listen to what they say about their teaching. The publication of Tomorrow's Doctors, coupled with these visits, has changed the issue from whether ethics and law should be part of the curriculum to how and what should be taught.

\section{The consensus statement}

Tomorrow's Doctors says little about what the syllabus in ethics and law should be. It is this issue which is the concern of the consensus statement. This statement has been agreed by the majority of those in the UK who are developing courses in these subjects.

If one were to look at medical ethics as it appears in the media one might think that it is primarily concerned with matters of reproductive 
ethics. Should older women be enabled to have children? Can a dead man's sperm be used for fertilisation? Should cloning be illegal? Such issues, although intellectually fascinating, rarely arise. However, ethical problems occur frequently in the practice of everyday medicine. The consensus statement has rightly emphasised this point. It stresses that the purpose of teaching ethics is to be clinically relevant and that the final aim is to create "good doctors who will enhance and promote the health and medical welfare of the people they serve". Elsewhere it states the aim of: "enabling students to understand that ethical and legal issues arise not only in extra-ordinary situations in medicine but also occur in everyday practice". The topics are consistent with this: consent; information-sharing and decision-making; confidentiality; the rights of children etc.

"Enabling students to think critically about ethical issues in medicine ... and to argue and counterargue in order to contribute to informed discussion and debate" is another aim specified in the consensus document. I have always seen the purpose of my teaching in this way. My aim is not to try and persuade students that a particular moral position is right, but to help them articulate their position and see how it stands up to counterarguments. This often entails, first arguing against one position, and if students find that too persuasive, giving, or encouraging students to give, arguments on the other side. In the student Christmas pantomime I was taken off as a character called "Hope-on-a-rope". This character descended onto the stage from his rope, in order to help the "goodies" solve a problem. Hope-on-a-rope was accompanied by a beautiful assistant (a fantasy of the medical students) who carried a "swingometer" which went from "perhaps" at one end of the spectrum to "maybe" at the other end. Arguments and counterarguments are important, but students do want some definite answers, even in medical ethics.

\section{Methods of teaching and assessment}

Are the fears of the professor of medicine justified? Would there be any shudder if it were suggested that there were an agreed core syllab $\underset{\underline{T}}{\mathrm{~T}}$ for cardiology? Quite the contrary, I imagine. The diagnosis and management of myocardial infare; the ability to read an electrocardiogram (ECGf, the analysis of an irregular pulse, would all form part of a core syllabus. It would be surprising agreement were not reached.

In contrast with the content of the course, the is little agreement in the consensus statement of the method of teaching. It states: "The specifica tion of these core issues is in no way meant to bet questions about how they are introduced, dis cussed and analysed throughout the curriculum? Each teacher and medical school has considerabile autonomy with regard to how best to teach, and what emphasis to adopt.

The development of ethics and law teaching UK medical schools has reached first base. TRe next stage, it seems to me, is to develop assessment methods. Students need to be assessed both to ensure that they reach a certain standara, and so that these subjects are taken serious $\vec{b}$. Assessment is also needed in order to discover which ways of teaching are most effective. For there is an important question raised by the sce tical position: does teaching work? Establishime the right outcome measures and assessing effe:tiveness is important. But, of course, this questi@ should be asked as vigorously with regard to the teaching of cardiology as it should with regard ethics and law.

Tony Hope is Editorial Associate of the Journal Medical Ethics, a Psychiatrist and Reader ign Medicine and Leader, Oxford Practice Skills Projegt, Oxford University, UK.

\section{References}

1 Teachers of medical ethics and law in UK medical schoọls Teaching medical ethics and law within medical educations model for the UK core curriculum. Fournal of Medical Ethits 1998;24:188-92.

2 General Medical Council. Tomorrow's doctors. London: Gene Medical Council, 1993. 